\title{
Pain management in Fissure-in-Ano by Invasive and Non-Invasive Methods: An Ayurvedic Review
}

\author{
Review Article
}

\section{Pradnya Bhagat ${ }^{1}$, Sekhar Namburi UR ${ }^{2 *}$, Savita Sharma ${ }^{2}$, Suryawanshi MN ${ }^{3}$}

\author{
1. Senior Research Fellow, 2. Research Officer (Sc-II), 3. Assistant Director and Incharge \\ Ayurveda Mental Health Research Institute, NIT Complex, \\ Gharkul Parisar, Nadanyan, Nagpur - 440009 (M.S)
}

\begin{abstract}
Fissure-in-ano (Guda-parikartika) is a tear, crack or ulcer in the anus which is one of the most troubling and painful surgical diseases that affect majority of the population. In Ayurveda it is mentioned as a sequel of some diseases or as a complication of some Panchakarma procedures or due to improper food habits and lifestyles leading to vitiation of Pitta dosha and develops indigestion in the patient which vitiates Apana vata and its functions which leads to fissure causing severe pain in the anal region along with severe spasm of Anal sphincter. Hence it becomes mandatory to pacify the Vata dosha for relieving pain which helps in relaxation of sphincter facilitating fissure healing. In this regard the various approaches are described in Ayurveda towards the Guda parikartika for controlling pain by correction of the Agni (Pachakagni) and Vatanulomana with multiple options by minimal invasive and noninvasive procedures. The invasive procedures are Kshara and Agnikarma, similarly noninvasive procedures are various medicated local applications and Basti therapies. However these therapeutic methods should be used judiciously as per the condition of the disease.
\end{abstract}

Key words: Gudaparikartika, fissure-in-ano, Ksharakarma, Ksharasutra, Agnikarma, Bastikarma.

\section{Introduction}

Guda parikartika (Fissure-in-ano) is named as it causes cutting type of pain in the anal region (1). In ancient Ayurvedic classics it was described briefly with various treatment principles and procedures. However, only Acharya Kashyap has described its types and

*Corresponding Author:

\section{Sekhar Namburi UR}

Research Officer (Sc-II)

Ayurveda Mental Health Research

Institute

NIT Complex, Gharkul Parisar

Nandanvan, Nagpur - 440009 (M.S)

Mobile No. 8055595355

Email add: shilpasekhar2k5@yahoo.com management as per the Doshic predominance (2).

In this disease the main predisposing factor is irregular food habits and lifestyles leads to constipation, which is one of the major causes along with other etiological factors like lack of local hygiene, pregnancy and following childbirth, post haemorrhoidectomy, inflammatory bowel diseases, particularly Crohn's disease and sexually transmitted diseases (3) - Similarly Acharya Sushruta mentioned various causes like improper instrumentation like rough and thick Basti Netra (enema nozzle) while doing the Basti karma (4) injudiciously performing the Panchakama procedures, iatrogenic due to ignorance of physician while performing some of the Panchakarma procedures like 
Vamana (therapeutic emesis), Virechana (therapeutic Purgation) and Basti Chikitsa (medicated enema) (5). Further Acharya Charaka mentioned fissure in ano as a complication of Vataj Atisara (6). In this regard Acharya Sushruta explained the pathogenesis of disease that if a person is debilitated, with Mrudu koshta (mild digestive power), Mandagni (poor appetite) in such conditions more intake of food having the qualities of Ruksha (dry), Ushana (hot), Lavana (salty) etc. vitiates Pitta and Vata and leads to manifestation of the disease (7). The common site of fissure seen in the anus is at posterior or sometimes anterior midline which is seen commonly in the females.

In Ayurvedic classics according to Acharya Kashyapa fissure-in-ano was classified in to three types (Vataja, Pittaja and Kaphaja) (2) and similarly Acharya Dalhana also mentioned two types (Vatolban and Pittolban) as per predominance of Doshas and features (8). Further the clinical features can be classified in to common and specific as per the various classical references. In this regard Acharya Sushruta mentioned that common and chief symptom is sharp cutting pain in the anal region (1) and also described other symptoms like cutting with burning sensation in the anus, umbilicus, penis and the neck of urinary bladder, retention of flatus and anorexia (9). Similarly Acharya Charaka mentioned almost same features and also its complications like rectal prolapse and faecoliths (10).

Regarding specific features Acharya Kashyapa described as mentioned below, based on Vata, Pitta and Kaphaja dosha predominance and character of pain in the anal region ${ }^{2}$.

1) Vatik Parikartika: Shooting, cutting and pricking type of pain.

2) Paittik Parikartika: Burning type of pain.

3) Shleishmik / Kaphaj Parikartika: Dull aching or itching type of pain.
In the contemporary medical science it is classified in to acute and chronic according to the onset and severity of the disease and with the clinical features of sharp, agonizing pain during defecation which may last for an hour or more. Many times patient may have painful bleeding with streak of fresh blood occurs at the end of defecation. However patient is comfortable until the next defecation, periods of remission occur for days to weeks. Due to severe pain during defecation, the patient tends to become constipated which results in passing of hard stools further deteriorating the problem and thus vicious cycle is formed. Hence to break this vicious cycle, it become very important to control the pain of the patient. This can be managed with various invasive and non-invasive procedures mentioned in Ayurvedic classcis as well as some procedures routinely used now a days in clinical practice apart from Ayurvedic literature.

Therefore the aim of this article is to throw light on various methods, procedures used for the pain management. Further the objective of the article is to evaluate the various available methods, procedures and to describe them with their particular indications practically used in current practice of Ayurvedic medicine and surgery.

\section{Management:}

The main objective of this disease is to relieve the pain which provides relaxation of sphincters, further it allows healing of fissure. This can be achieved by correction of the vitiated Vata and Pitta doshas, as these two are basic factors in manifestation of disease. In this regard various Non-invasive and Invasive methods were described by different Acharyas in Ayurveda. The main non-invasive methods are Oushadha chikitsa (administration of drugs) and Basti therapy (medicated enema). Similarly invasive methods are Kshara karma, Ksharsutra application and 
Agnikarma (cauterisation). These methods of treatment can be used based on condition of the disease and patient. Further Acharya Kashyapa stated that treatment should be based on Doshic predominance in Guda parikartika (2).

\section{Non-Invasive methods Oushadhi chikitsa}

In this disease the main vitiated Doshas are Vata and Pitta. Therefore administration of sour (Amla Rasa Dravyas) and soft items are advisable as these corrects the Pitta as well as Vata by increasing Agni-deepana (appetite) and Vataanulomana respectively (11). Further the drugs like Mrudurechaka (mild laxatives), Shothahar (anti-inflammatory) drugs as well as Vranaropaka (promoting wound healing) anointments will helpful to control constipation and pain which are main features of the disease. Regarding the food habits Acharya Charaka advised milk diet (12). These diet changes are helpful in rectification of vitiated Doshas as well as enhancing potency of drugs which helps early recovery from this disease.

\section{Basti Chikitsa}

Almost all ancient authors focused on Basti Chikitsa while treating fissure-inano as it pacifies vitiated Vata which is one of the main factor for pain. Particularly Basti prepared with Taila (oils), Ghrita and milk which are processed with various drugs further helps in controlling the pain and further assists in early recovery. Acharya Sushruta and other Authors of Ayurveda advised Pichha basti and Anuvasana basti fortified with Yashtimadhu and Ghrit mand for this ailment.

The Pichha basti is prepared as described by Acharya Charaka in Siddhisthana which mainly contains Yashtimadhu (Gly.gabra) and paste of Sesame seeds mixed in Ghee (clarified butter) and honey (12). This Pichha basti acts as Vata-Pitta Shamaka and Vrana ropaka, which finally helps in controlling the pain.

Sneha (Anuvasana) basti is also useful in this disease and it is to be given with medicated oil / ghee which is prepared with Yashtimadhu (Gly.gabra) (1) . Basti can be used in modified method by $10 \mathrm{ml}$ of oil like Anu Taila or Narayana Taila or Yashtimadhu Taila or Jatyadi Taila etc is administered before and after defecation is in practice with promising results.

\section{Invasive Methods \\ Kshara application}

Acharya Sushruta defined the Kshara as the substance possessing Ksharana (localized cleansing properties) and Kshanan (debridement) properties (13). He advocated Ksharakarma for the Shodhana (purification) of a long standing ulcer which is having the features like induration, raised margins and is marked by itching (14). On this principle Kshara is used for Shodhana (purification) and Lekhana (debridement) of unhealthy tissue seen on the bed of chronic fissure which ultimately reduces the pain by controlling induration and inflammation.

Procedure: Fissure is isolated and visualized properly by introducing a lubricated slit proctoscope in lithotomy position. Then approximately $500 \mathrm{mg}$. of Apamarga kshara is to be taken on cotton swab wrapped on carried mosquito forceps is applied on fissure bed and to be kept for 100 seconds. Later the site should be washed thoroughly with lemon juice.

\section{Agnikarma}

Agnikarma (therapeutic thermal cauterisation) is one of the para-surgical procedure is very much useful and gives good relaxation to the anal sphincters, relieves pain and promotes healing in fissure. The indication of Agnikarma for the Guda parikartika is not advised in the classics of Ayurveda, but this procedure has been explained in painful Vataja Arsha chikitsa. In this context, based on the 
properties (15) and mode of action (16) of this procedure has been selected in the ailment. Some research scholars have published papers which clearly depicts the efficacy of Agnikarma in fissure in ano

Procedure: Patient was taken in lithotomy position under spinal or local anesthesia. After achieving proper analgesia and relaxation, manual anal dilatation to be done up to four fingers lubricated with local analgesic jelly. Then sentinel tag should be excised by electric cautery. Later visualize the fissure by gentle stretching of the anus with help of assistant, then denuding of the fissure by cutting few fibers of the sphincters through the bed of fissure resulting in the relaxation of the sphincters. Finally application of Yastimadhu ghrita or any Pittahara anointments may be used for the rectal pack over Sudagdha vrana to avoid the postoperative complications.

\section{Ksharasutra}

Ksharasutra application has been described in the management of fistula-inano in Ayurveda. However it can be used based on its properties. This procedure can be under local anaesthesia under strict measures. Patient should be kept in lithotomy position, then with help of round curved needle few fibers of internal sphincter to be taken along with bed of fissure. Later it should be tied and Ksharasutra should be changed for every week till it will get cut. This procedure helps in relaxation of sphincter by cutting few of its fibres gradually and patient get relief in the pain.

On Agnikarma and Ksharsutra procedures various clinical studies have been conducted and proved to be beneficial in different types of fissures. ${ }^{17,18}$

\section{Discussion}

The vital symptom of this disease is severe pain in anus causing spasm of anal sphincter. Hence pain management is first step as it relieves the sphincter spasm and improves local circulation which results in the rapid healing of the fissure. As per Ayurveda the whole patho-physiology of disease is due to vitiation of Vata and Pitta and the treatment is aimed to pacify Vata and Pitta dosha. In Ayurvedic classics various management methods were described in various contexts these should be used with caution as per the condition of the disease and patient. In this regard Oushadha Chikitsa is first line of management and it should be given with respect to any procedure as it causes Deepana and Vatanulomana. While Anuvasana Basti useful in the chronic fissures, Piccha basti is advisable if fissures are secondary to the intestinal diseases. Similarly invasive procedures like Ksharakarma are useful in chronic fissures with slough and unhealthy fibrous tissue. The application of Ksharsutra is advisable only in the chronic fissures along with severe sphincter spasm. Similarly Agnikarma is indicated in acute fissures with sentinel tag and severe sphincter spasm.

\section{Conclusion:}

Gudaparikartika is a common clinical entity mainly caused due to vitiation of Vata and Pitta Dosha and its incidence varies substantially by age and sex with intolerable pain at anal region and always disproportionate to the severity of the physical lesion. Therefore pain management has got prime importance in the treatment of fissure by pacifying vitiated Apanavata which can be achieved with selection of either Invasive or Noninvasive methods. Pain management through these procedures not only helps in healing of fissure but also avoids recurrence. Hence various methods like Agnikarma and Ksharkarma explained at various contexts in the classics of Ayurveda can be implemented in the management of diseases with caution and can be successfully practiced in present days 
though they are not particularly indicated for fissure.

\section{References:}

1. Sharma P V, editor, ( ${ }^{\text {st }}$ ed.). Sushruta Samhita of Sushruta. Vol. II Chikitsasthana, chapter Vamanvirechan Vyapat Chikitsitam 34/16; Varanasi: Chaukhambha Vishwabharti Publishers.pg 595

2. Pandit Hemaraja Sharma, editor, $\left(3^{\text {rd }}\right.$ edition) Kashyapa Samhita of Kashyapa, Khilasthana, Antarwali Chikitsadhyay 10/102-105, Varanasi: Chaukhambha Orientalia Publishers; 1976 pg.299

3. Dr. K. Rajgopal Shenoy, Consultant Surgeon, KMC Hospital, Manipal, Professor of Surgery, KMC, Manipal Academy of Higher Education, Manipal Manual of Surgery, $2^{\text {nd }}$ Edition, CBS Publishers \& Distributors, New Delhi, 2008.

4. Sharma P V, editor, ( $1^{\text {st }}$ ed.). Sushruta Samhita of Sushruta, Vol. II Chikitsasthana, chapter Netrabastipramanpravibhaga

Chikitsitam 35/32, Varanasi: Chaukhambha Vishwabharti Publishers; 2005 pg.606

5. Sharma P V, editor, $\left(1^{\text {st }}\right.$ ed. $)$. Sushruta Samhita of Sushruta, Vol. II Chikitsasthana, chapter Vamanvirechan Vyapat Chikitsitam 34/3, Varanasi: Chaukhambha Vishwabharti Publishers; 2005 pg.588

6. Priyavat sharma, editor, ( $1^{\text {st }}$ ed.). Charaka samhita of Charaka, Vol. II Chikitsasthana, chapter Atisar Chikitsitam 19/05. Varanasi: Chaukhambha Orientalia Publishers; 2008, pg 320
7. Sharma P V, editor, ( $1^{\text {st }}$ ed.). Sushruta Samhita of Sushruta, Vol. II, Chikitsasthana, Vamanvirechan Vyapat Chikitsitam 34/16., Varanasi: Chaukhambha Vishwabharti Publishers; 2005pg.595

8. Vaidya Yadavaji Trikamji Acharya, editor, (Ed 2009), Sushruta, Sushruta Samhita, commentary Dalhanacharya Virachita, Nibandhsangrahvyakhya Sanvalita on Sushruta Samhita of Sushruta, Chikitsasthana, Chapter Vaman Virechana Vyapatchikitsa 34/16, Chaukhambha Sanskrit Sansthan, Varanasi, India pg.524

9. Sharma P V, editor, ( $1^{\text {st }}$ ed.). Sushruta Samhita of Sushruta. Vol. II Chikitsasthana, chapter Vamanvirechan Vyapat Chikitsitam 34/ 16 pg.595

10. Priyavat sharma, editor, ( $1^{\text {st }}$ ed.). Charaka samhita of Charaka, Vol. II Chikitsasthana, chapter Atisar Chikitsitam 19/ 05, Varanasi: Chaukhambha Orientalia Publishers; 2008 pg.320

11. Priyavat sharma, editor, ( $1^{\text {st }}$ ed.). Charaka samhita of Charaka, Vol. II Sidhdhisthana, chapter Bastivyapatsidhdhi 7/57, Varanasi: Chaukhambha Orientalia Publishers; 2008; pg.637

12. Priyavat sharma, editor, ( $1^{\text {st }}$ ed.). Charaka samhita of Charaka, Vol. II Sidhdhisthana, chapter Bastivyapatsidhdhi 7/56 6/63-66, Varanasi: Chaukhambha Orientalia Publishers; 2008; pg.637

13. Sharma P V, editor, ( $1^{\text {st }}$ ed.). Sushruta Samhita of Sushruta. Vol. 1 Sutrasthana, chapter Ksharapakvidhiadhyay 11/4 Varanasi: 
Chaukhambha Orientalia Publishers; 2008 pg 113

14. Sharma P V, editor, ( $1^{\text {st }}$ ed.). Sushruta Samhita of Sushruta. Vol II, Chikitsa sthana, chapter DvivraniyaChikitsitam, 1/88 Varanasi: Chaukhambha Orientalia Publishers; 2008 pg 265

15. Sharma P V, editor, ( $1^{\text {st }}$ ed.). Sushruta Samhita of Sushruta. Vol. 1 Sutrasthana, chapter 12, Shloka 16 pg128

16. Sharma P V, editor, ( $1^{\text {st }}$ ed.). Sushruta Samhita of Sushruta. Vol. 1 Sutrasthana, chapter 6 Shloka 6 pg 75
17. Dudhamal TS, Baghel MS, Bhuyan C, Gupta SK4, Role of Ksharasutra suturing along with adjuvant therapy in the management of Parikartika (Chronic fissure-in-ano), International Journal of Ayurvedic Medicine, 2013, $4(1), \quad 77-86, \quad$ available on www.ijam.co.in/index.php/ijam/article /download/232/174

18. Aparna A, Dr.Gururaja D, A Clinical Study Onrole Of Agnikarma W.S.R To Cauterizationin The Management Of Chronic Fissure In Ano, 2012-2013, Available on www.rguhs.ac.in/cdc/onlinecdc/uploa ds/03_A042_41839.doc 